\title{
An Interactive e-Book for Physics to Improve Students' Conceptual Mastery
}

\author{
https://doi.org/10.3991/ijet.v15i05.10967 \\ Ahmad Harjono ${ }^{\bowtie}$, Gunawan Gunawan \\ Universitas Mataram, Mataram, Indonesia \\ harjonofkipeunram.ac.id \\ Rabiatul Adawiyah \\ Universitas Islam Negeri Mataram, Mataram, Indonesia \\ Lovy Herayanti \\ IKIP Mataram, Mataram, Indonesia
}

\begin{abstract}
Rotational dynamics is one of topic in physics for high school students that require visualization of its concepts. This research developed an interactive e-book for physics learning with its features consisting of multimedia content such as audio, video, animation, and simple problem-solving activities. This e-book has been validated and recommended by a team of experts. This trial aims to determine the effectiveness of e-book by students in mastering concepts, using a. quasi-experiment. The sample was chosen using purposive sampling technique at senior high school with 42 students. Data were collected using multiple choice questions. The increase of student concept mastery is determined based on the $\mathrm{N}$-gain score of pretest and posttest data. The results show that the average student response to e-book is $81 \%$ in the very good criterion. The $\mathrm{N}$-gain scores for the equilibrium concepts of $\mathrm{A}$ and $\mathrm{B}$ classes are 0.79 and 0.70 in the high criteria, while, the concept of rotational dynamics are 0.66 and 0.66 respectively and in the medium criterion. The increase of conceptual mastery occurs in every cognitive domain (remembering, understanding, applying, analyzing, evaluating, and creating). In conclusion, the e-book has been effective in enhancing the mastery of student concepts.
\end{abstract}

Keywords-Interactive e-book, rotational dynamics, conceptual mastery

\section{Introduction}

The e-book is a digital version of the traditional printed book read on a personal or desktop computers, laptops, smartphones, tablets, or e-book readers [1]. Therefore, the Indonesian government, through the Ministry of Education and Culture, has provided e-books for schools which are accessible online in PDF format (Portable Display Format).

E-book PDFs are designed like a printed book and cause significant eye effect [2], such as dry eyes, ocular discomfort, headache, and other visual symptoms [3]. Users 
tend to read quickly to obtain main points. However, this is not optimally utilized because limited learning message is acquired, and the concept is not fully conveyed.

Lately, e-books have been designed with more interactive features such as audio, video, slideshows, and image galleries [4]. In addition, there are multimedia which links manually users [5]. There are also variables in the interactive e-book diagrams, symbols, signs, shapes, and tools which supports thinking skills [6].

Concepts are defined as abstractions of various events, objects, phenomena, and facts comprising of special attributes. Generalization helps to classify and organize knowledge and experience [7]. The concept marks on an object which helps students to understand and directly visualize the abstract models through a real laboratory [8]. Similarly, the virtual labs are an alternative to physics experiments and help visualize abstract concepts such as ' Rotational Dynamics [9]. Previous research has shown that the level of 'conceptual mastery' of students on the subject of Rotational Dynamics is low. There is a fundamental error [10] and high misconception [11]. This problem is solved by developing teaching materials such as e-books with variety of benefits such as improving motivation for beginner readers [12], enhancing children's understanding and literacy [13] and enabling parents and teachers to provide an efficient and enjoyable learning experience [14].

This type of media also provides an opportunity to develop conceptual mastery in any physics matters. Hermansyah et al. [15] stated that virtual labs could improve students' understanding of heat concept. Gunawan et al. [16] also found that interactive simulation could improve students' conceptual understanding universally in physics learning. Both e-book and virtual lab are computer-based media, which helps students increase their conceptual mastery, of physics and other courses. The teaching material that has been developed is an interactive e-book on physics learning. Its content is 'Rotational Dynamics' which has been designed using Adobe Flash Professional CS5 with Action Script 3.0. Furthermore, the integration of multimedia makes it more interactive. In high school, 'Rotational Dynamics' is parallel to the 'Equilibrium of rigid bodies' competence. Therefore, the developed e-book has two basic concepts, namely equilibrium and rotational dynamics.

\section{$2 \quad$ Method}

This study is a quasi-experiment with the design of 'one group pre and post-test' as shown in Table 1. It comprises of a total of 42 high school students grouped into two experimental groups, namely A and B.

Table 1. Reseach Design

\begin{tabular}{|c|c|c|c|}
\hline Groups & Pre-test & Independent Variables & Post-test \\
\hline Experiment & $\mathrm{O} 1$ & $\mathrm{X} 1$ & $\mathrm{O} 2$ \\
\hline
\end{tabular}

Each group is given a pre-test through 24 items of multiple choice questions which consists of 12 items on the concept of 'Equilibrium of rigid bodies,' and the 'Rotational Dynamics.' Furthermore, students are given treatment by applying an interactive e- 
book of physics as the main teaching material. The learning process is conducted for four sessions with each allocated a 90 minutes timeframe. In early learning, teachers prepared an 'e-book interactive physics' on computers for 2-3 students, therefore, making it possible for learning to take place as facilitators. The final stage is a posttest containing the same question as to the pre-test.

The data obtained were quantitative and analyzed by the normalized gain test $(\mathrm{N}$ Gain). This aims to determine the improvement of conceptual mastery in both classes. The N-gain equation is:

$$
\mathrm{N}-\text { gain }=\frac{\text { Post test-Pre test }}{\text { Maximum Score-Pre test }}
$$

Table 2. Interpretation of $\mathrm{N}$-gain Score

\begin{tabular}{|l|l|}
\hline \multicolumn{1}{|c|}{ N-gain } & \multicolumn{1}{c|}{ Criteria } \\
\hline$N-$ gain $>0.70$ & High \\
\hline $0.70 \geq N-$ gain $\geq 0.30$ & Medium \\
\hline$N-$ gain $<0.30$ & Low \\
\hline
\end{tabular}

Each score is interpreted to be a low, medium, and high criterion (Table 2). The test result score is converted to a total value of 100 on a scale to obtain the average value of each experimental class. The analysis was performed on every major concept and cognitive domain, according to Bloom's taxonomy [17]. The domains include remembering $(\mathrm{C} 1)$, understanding $(\mathrm{C} 2)$, applying $(\mathrm{C} 3)$, analyzing $(\mathrm{C} 4)$, evaluating (C5), and creating (C6).

\section{$3 \quad$ Result}

Physical interactive e-book profiles as teaching materials to enhance students' conceptual mastery are shown in Table 3. This product has been validated by a team of experts comprising of materials, media, and practitioners (physics teachers). The results show that the interactive e-book design is 'Feasible' to be used as teaching material in physics learning.

Table 3. Profile of E-book Interaktif for Physics

\begin{tabular}{|c|l|l|}
\hline No. & \multicolumn{1}{|c|}{ Type of Design } & \multicolumn{1}{c|}{ Result } \\
\hline 1 & The Name of the Product & E-book interactive for physics \\
\hline 2 & Extension & exe \\
\hline 3 & Material content & Equilibrium rigid body and Rotational dynamic \\
\hline 4 & Media content & Video, animation, and audio \\
\hline 5 & Learning activities & $\begin{array}{l}\text { Finding facts, making temporary allegations, looking for } \\
\text { learning information, making problem answers, Exercises. }\end{array}$ \\
\hline
\end{tabular}

Each group is given a pre-test through 24 items of multiple choice questions. The question consists of 12 items of concept 'Equilibrium of rigid bodies,' and the other is on 'Rotational Dynamics.' Furthermore, students are given treatment by applying an 
interactive e-book of physics as the main teaching material in Rotational Dynamics. The learning process is conducted for four sessions with a 90 minutes timeframe for each. In early learning, teachers prepared an 'e-book interactive physics' on computers for 2-3 students, thereby making students learn independently with teachers as facilitators. The final stage is a post-test containing the same question as to the pre-test.

Table 4. N-Gain Score The Concept of Equilibrium and Rotational Dynamics

\begin{tabular}{|l|l|c|c|}
\hline \multirow{2}{*}{ Materials } & \multirow{2}{*}{ Test } & \multicolumn{2}{|c|}{ Average Score } \\
\cline { 3 - 4 } & & Group $\boldsymbol{A}(\mathbf{N = 2 6})$ & Groups $\boldsymbol{B}(\mathbf{N = 1 6})$ \\
\hline \multirow{3}{*}{ Equilibrium } & Pre-test & 22.12 & 20.83 \\
\cline { 2 - 4 } & Post-test & 83.33 & 75.93 \\
\cline { 2 - 4 } & N-gain & 0.79 & 0.70 \\
\hline \multirow{3}{*}{ Rotational Dynamics } & Pre-test & 30.13 & 3.090 \\
\cline { 2 - 4 } & Post-test & 76.19 & 75.93 \\
\cline { 2 - 4 } & N-gain & 0.66 & 0.66 \\
\hline
\end{tabular}

Table 4 shows the N-gain scores of groups A and B. Group A's score with a sample size of 26 students on the concept of equilibrium of a rigid body' is 0.79 . According to Table 3, this score is 'high- criterion,' and the concept of Rotational Dynamics material is 0.66 (medium criterion). Meanwhile, group B with a sample size of 16 students, and $\mathrm{N}$-gain scores for the concept of equilibrium and Rotational Dynamics are 0.70 (high criterion) and 0.66 (medium criterion).

$\mathrm{N}$-gain scores of each cognitive domain are shown in Table 5. The mean scores of each cognitive domain have increased based on pre-test and post-test. Group A is highly criteria for domains $\mathrm{C} 1, \mathrm{C} 2, \mathrm{C} 3$, and C5. However, medium criteria are obtained in $\mathrm{C} 4$ and $\mathrm{C} 6$. Furthermore, group $\mathrm{B}$ is in the highly criteria on $\mathrm{C} 1$ and $\mathrm{C} 2$ domains while $\mathrm{C} 3, \mathrm{C} 4, \mathrm{C} 5$, and $\mathrm{C} 6$ are medium criteria

Table 5. N-Gain Score for Cognitive Domains

\begin{tabular}{|l|l|c|c|c|c|c|c|}
\hline \multirow{2}{*}{ Group } & \multirow{2}{*}{ Test } & \multicolumn{7}{c|}{ Average Score } \\
\cline { 3 - 8 } & & $\boldsymbol{C 1}$ & $\boldsymbol{C 2}$ & $\boldsymbol{C 3}$ & $\boldsymbol{C 4}$ & $\boldsymbol{C 5}$ & $\boldsymbol{C 6}$ \\
\hline \multirow{3}{*}{ Group A } & Pretest & 41.03 & 36.54 & 3.73 & 7.69 & 2.56 & 0.00 \\
\cline { 2 - 8 } & Posttest & 87.18 & 85.90 & 79.33 & 70.51 & 83.33 & 46.15 \\
\cline { 2 - 8 } & N-gain & 0.78 & 0.78 & 0.79 & 0.68 & 0.83 & 0.46 \\
\hline \multirow{3}{*}{ Group B } & Pretest & 14.58 & 20.83 & 27.34 & 22.92 & 47.92 & 25.00 \\
\cline { 2 - 8 } & Posttest & 85.42 & 85.42 & 68.75 & 66.67 & 77.08 & 75.00 \\
\cline { 2 - 8 } & N-gain & 0.83 & 0.82 & 0.57 & 0.57 & 0.56 & 0.67 \\
\hline
\end{tabular}

\section{Discussion}

The results of the analysis indicate that the interactive e-book is effective to improve the mastery of Rotational Dynamics by students in two schools. These results are in line with previous research by Darlen et al. [18] and Cahyanti et al. [19], which shows that the integration of multimedia in e-books is effective in enhancing students' conceptual understanding. 
The process requires many factors which must support it such as creativity which sometimes appear after or before mastering the concepts. In general, computer-based media such as e-books have proven to be able to support these capabilities. Research conducted by Adawiyah et al. [20] showed that e-books were able to improve students' creative thinking skills. This is also similar to the research conducted by Gunawan et al. [21], which concluded that the use of virtual lab media improves student creativity. Creativity is defined as the result of good understanding of the concepts with the ability to provide computer-based media and increase in students' understanding and support of good physics concepts.

Learning activities in this study were conducted in groups, which allow interaction between students. Tsang [22] revealed that interaction between students triggers the exchange of information, complement, and create active learning. Group learning increases students' positive activities, while, the active students tend to score high. Flexibility and freedom to explore capabilities independently improve their learning abilities [23].

The learning outcomes of groups A and B are concept mastery data, comprising of pre-test data (before treatment) and post-test (after treatment) which are multiple choice tests. Researchers made use of multiple-choice tests to facilitate scores and assessment. Simkin \& Kuechler [24] stated that multiple-choice tests are the most popular test because they are easy to assess, practical, and is a basis for analyzing students' understanding of learning.

The average score of the two schools on the pre-test is low because it has not reached the minimum standard of learning completeness of 75 . This is due to the administration of the pre-test before learning. However, the average score of students in the cognitive domain is high $(\mathrm{C} 1, \mathrm{C} 2$, and $\mathrm{C} 3)$ owing to the higher level of difficulty and cognitive domains. This case corresponds to the average score in group A, which states that the higher the cognitive domain, the lower the score.

Different results occurred in group B. Based on Table 5, the average score of each cognitive domain approached the same result because the ranged values were small. The difference between the domains is not dominant from $\mathrm{C} 1$ to $\mathrm{C} 6$ and greater in $\mathrm{C} 5$. This needs to be questioned, as there is inconsistency with the material that has been described in group A. Based on the instrument used (multiple choice), the student's chance to guess the correct answer is pretty much on the subject that the student has never learned before. One of the weaknesses of multiple choice questions is the numerous opportunities to guess the right answers.

Post-test results of the concept of equilibrium and Rotational Dynamics in both groups have increased based on pretest. Therefore, the average score of the two schools is declared complete. This increase is due to the learning treatment provided. Learning to use interactive e-book media provides students with an opportunity to learn independently (student-centered). These results are in line with Efe et al. [25], which revealed that learning through animation increases their confidence because visual effects enhances affective, cognitive, and understanding a. The post-test average score on equilibrium is higher than the concept of Rotational Dynamics. This is due to the high level of cognitive domain question in the concept of Rotational Dy- 
namics, which is correctly answered by some students. Finally, the average score is lower than the equilibrium concept.

The $\mathrm{N}$-gain equation determines the improvement of concept mastery based on pretest and post-test. It is performed to determine the mean value of each concept in the 'Rotational Dynamics of each cognitive domain. The results show that the $\mathrm{N}$-gain for equilibrium concept in group A is close to B score. The second group score is interpreted in high criterion, which means that the improvement of mastery of the concept before and after treatment with physics interactive e-book is 'high'.

The $\mathrm{N}$-gain score for the concept of Rotational Dynamics in Group A is closer to B. This value includes medium criterion, which means that increasing the mastery of the concept in both schools is in the medium category. Comparison of each concept of Rotational Dynamics shows that group A is always higher than B. As a result, the average pre-test in group $\mathrm{A}$ is always smaller than $\mathrm{B}$, and in the mean post-test the two schools approach each other. Therefore, group A rises higher than group B.

Table 5 shows the difference between the pre-test and post-test scores of both groups. The $\mathrm{N}$-gain value for the cognitive domain of $\mathrm{C} 1$ in group $\mathrm{A}$ is smaller than in B. However, this value is highly criteria. This means that the increase in the $\mathrm{C} 1$ domain of both groups is high which is due to the learning experience of students with an interactive e-book. The e-book presents an explanation of a concept with a short and simple language to enable students to easily remember its definition through the explanation presented. Learners using interactive electronic books have a more active and relaxed attitude because they propose solutions to computers independently [26].

Each student has a high criterion on domain $\mathrm{C} 2$. This result is the impact of using e-book equipped with the elaboration of concepts and examples to strengthen students' understanding. Small discussion groups in the learning activities which takes place, is able to overcome misunderstandings of students. The uses of features in computers such as PowerPoint helps students understand Physical phenomena, thereby, helping them to understand Physics [27].

The N-gain scores on the C3 domains of groups A and B are distinctly different from the range of values, with the first having a high criterion and the second a medium criterion. The average pre-test scores of each group differed significantly where group A was 3.73, and group B 27.34. While the post-test average scores of both groups were 79.33 and 68.75 , respectively, average difference of pre-test and the posttest for group A is higher than that of B (group B obtains a very large average pretest value) therefore, the $\mathrm{N}$-gain will be different. Similarly, in domain $\mathrm{C} 5$, group $\mathrm{A}$ increases with 'high criterion' and B with medium. This situation is caused by multiple choice patterns giving students a great chance to guess the correct answer during pretest.

The N-gain for C4 domains in groups A and B was 0.68 and 0.57 , respectively by medium criterion. Therefore, both schools experienced the same improvement for $\mathrm{C} 4$ domains. Although the criteria are the same based on the average score, group A is higher than B. Similarly group B is caused by the high average pre-test value therefore, the post-test increase the medium.

The domain C6 is almost similar to the $\mathrm{C} 4$, the difference is that the C6 of group B is higher than A where the $\mathrm{N}$-gain score for group B is 0.67 and 0.46 for A. In this 
domain, the average score of group A is zero (0) because most students' answers are wrong. The test items on this domain are the most difficult, as evidenced by the difference in average pre-test and post-test in group A which are categorized as medium. Likewise, with group B, the average score of pre-test and post-test is in the high category. Therefore, the $\mathrm{N}$-gain score is in the medium criterion.

The application of an interactive eBook is effective to increase the mastery of the concept of Equilibrium rigid body and Rotational Dynamics. The mix of audiovisual content such as animation, video, images, and text make it easier for students to understand the concept. Learning using physics e-books helps students understand abstract concepts. Hermansyah et al. [28] found that the use of interactive multimedia improves creative thinking skills and the mastery of student concepts.

The application of interactive e-books as the main 'teaching materials' in learning activities affects the mastery of student concepts. An interactive e-book maximizes direct learning. Collaboration between direct learning and computer-based media such as e-books has proven to support students. Research conducted by Sumtsova et al. [29] stated that without doubt, collaborative learning is an active method of teaching and is very effective as it combines all the recent trends and developments in the field of mastering. Bi \& Shi [30] stated that computer-assisted teaching is recognized by both teachers and students and effectively improve teaching effects. Based on this, the application of e-book and direct learning has proven to be empirically and theoretically capable of supporting learning. With good learning, this leads to an increase in understanding the concept of students.

The future of the e-book is quite promising. Research by Abuloum et al. [31] stated that students have a positive response to the use of digital books, although they have not matched the level of readability of printed books. Low e-book usage is due to the use of devices not comfortable to the human eye. A computer screen or tablet is not good when used continuously over a long period. This is one of the biggest weaknesses of e-book. However, it will continue to grow both in quality and technologically. In the future, the e-book is expected to overcome its shortcomings with the application of a screen that is more comfortable for the eyes, such as a screen with a blue light filter.

\section{Conclusion}

The interactive e-book contains videos, animation, audio, and simple problem solving activities in everyday life, effective for improving students' concept and mastery. The results show improvement with 'high criteria' on equilibrium and 'medium criteria' on Rotational Dynamics. Increased mastery of concepts also occurs in each domain of knowledge (cognitive domain). The cognitive enhancement criteria of groups $\mathrm{A}$ and $\mathrm{B}$ are 'high' in $\mathrm{C} 1$ and $\mathrm{C} 2$, and 'medium' for $\mathrm{C} 4$ and $\mathrm{C} 5$ domains. Different criteria were found in the two domains, where group A contained C3 and C5 domains which received high improvement criteria, and B was medium criteria. 


\section{Acknowledgement}

The authors are grateful to all those who helped in the development of e-books, research processes, data collection, and improvements to this article, especially those at the research center for physics and technology education, University of Mataram.

\section{$7 \quad$ References}

[1] Zivcovic, D. (2008). The Electronic Book: Evolution or Revolution? Degișen Dünyada Bilgi Yönetimi Sempozyuтu, 9(1), 1-19.

[2] Jeong, H. (2012). A comparison of the influence of electronic books and paper books on reading comprehension, eye fatigue, and perception. The Electronic Library, 30(3), 390408. https://doi.org/10.1108/02640471211241663

[3] Rosenfield, M. (2011). Computer vision syndrome: a review of ocular causes and potential treatments. Ophthalmic and Physiological Optics, 31(5), 502-515. https://doi.org/10.1111/ j.1475-1313.2011.00834.x

[4] Fenwick Jr, J. B., Kurtz, B. L., Meznar, P., Phillips, R., \& Weidner, A. (2013). Developing a highly interactive ebook for CS instruction. In Proceeding of the 44th ACM technical symposium on Computer science education (pp. 135-140). ACM. https://doi.org/10.1145/ 2445196.2445241

[5] Ebied, M. M. A., \& Rahman, S. A. A. (2015). The Effective E-Book on Students Achievement at Najran University in Computer in Education Course. Journal of Education and Practice, 6(9), 71-82.

[6] Mashami, R. A., \& Gunawan, G. (2018). The Influence of Sub-Microscopic Media Animation on Students' Critical Thinking Skills Based on Gender. In Journal of Physics: Conference Series. 1108 (1) p. 012106. https://doi.org/10.1088/1742-6596/1108/1/012106

[7] Beetlestone, F. (2011). Creative Learning. Bandung: Nusa Media.

[8] Hermawanto, Kusairi, S., \& Wartono. (2013). Pengaruh Blended Learning terhadap Penguasaan Konsep dan Penalaran Fisika Siswa Kelas X. Jurnal Pendidikan Fisika Indonesia, 9(1), 67-76. https://doi.org/10.15294/jpfi.v12i2.4269

[9] Gunawan, G., Harjono, A., Sahidu, H., \& Herayanti, L. (2017). Virtual Laboratory to Improve Students' Problem-Solving Skills on Electricity Concept. Jurnal Pendidikan IPA Indonesia, 6(2), 257-264. https://doi.org/10.15294/jpii.v6i2.9481

[10] Amnirullah, L. (2015). Analisis Kesulitan Penguasaan Konsep Mahasiswa pada Topik Rotasi Benda Tegar Dan Momentum Sudut. Jurnal Fisika Indonesia, 19(56), 34-37. https ://doi.org/10.22146/jfi.24356

[11] Mulyastuti, W. S., \& Jauhariyah, R. (2016). Profil Reduksi Miskonsepsi Siswa Materi Dinamika Rotasi Sebagai Pengaruh Penerapan Model Pembelajaran ECIRR Berbantuan Media Audiovisual. Inovasi Pendidikan Fisika, 5(2), 82-84.

[12] Ciampa, K. (2012). Reading In Digital Age: Using Electronic Books as A Teaching Tools For Beginning Readers. Canadian Journal of Learning and Technology, 38 (2), 1-26.

[13] Grimshaw, S., Dungworth, N., McKnight, C., \& Morris, A. (2007). Electronic books: Children's reading and comprehension. British Journal of Educational Technology, 38(4), 583-599. https://doi.org/10.1111/j.1467-8535.2006.00640.x

[14] Korat, O. (2010). Reading electronic books as a support for vocabulary, story comprehension and word reading in kindergarten and first grade. Elsevier Computer and Education, 55(1), 24-31. https://doi.org/10.1016/j.compedu.2009.11.014 
[15] Hermansyah, H., Gunawan, G., Harjono, A., \& Adawiyah, R. (2019). Guided inquiry model with virtual labs to improve students' understanding on heat concept. In Journal of Physics: Conference Series. 1153 (1) p. 012116. https://doi.org/10.1088/1742-6596/1153/1 1012116

[16] Gunawan, G., Nisrina, N., Suranti, N. M. Y., Herayanti, L., \& Rahmatiah, R. (2018, November). Virtual Laboratory to Improve Students' Conceptual Understanding in Physics Learning. In Journal of Physics: Conference Series. 1108 (1), p. 012049. https://doi.org/ 10.1088/1742-6596/1108/1/012049

[17] Anderson, L. W., \& Krathwol, D. R.2001. A Taxonomy for Learning, Teaching, and Assessing: A Revision of Bloom's Taxonomy of Educational Objectives. A Bridged Edition. New York: David McKey Company. Inc.

[18] Darlen, R. F., Sjarkawi \& Lukman, A. (2015). Pengembangan E-Book Interaktif untuk Pembelajaran Fisika SMP. Jurnal Tekno-Pedagogi, 5(1), 13-23.

[19] Cahyanti, R. D., \& Akhlis, I. (2015). Pengembanan E-Book sebagai Implementasi Model Pembeajaran Inkuiri Terbimbing Materi Mesin Atwood untuk Siswa SMAN 1 Kradenan. Unnes Physics Education Journal, 4(1), 22-25.

[20] Adawiyah, R., Harjono, A., Gunawan, G., \& Hermansyah, H. (2019). Interactive e-book of physics to increase students' creative thinking skills on rotational dynamics concept. In Journal of Physics: Conference Series. 1153 (1), p. 012117. https://doi.org/10.1088/1742$\underline{6596 / 1153 / 1 / 012117}$

[21] Gunawan, G., Suranti, N. M. Y., Nisrina, N., Herayanti, L., \& Rahmatiah, R. (2018). The effect of virtual lab and gender toward students' creativity of physics in senior high school. In Journal of Physics: Conference Series. 1108 (1), p. 012043. https://doi.org/10.1088/17 $\underline{42-6596 / 1108 / 1 / 012043}$

[22] Tsang, A. (2011). In-class reflective group discussion as a strategy for the development of students as evolving professionals. International Journal for the Scholarship of Teaching and Learning, 5(1), 7. https://doi.org/10.20429/ijsotl.2011.050107

[23] Adri, M., \& Azhar, N. (2008). Pengembangan Paket Multimedia Interaktif Sebagai Sarana Belajar Mandiri Mahasiswa. In Makalah dipresentasikan pada Seminar Nasional Konstribusi Pendidikan Jarak Jauh (PJJ) dalam Pencapaian Milenium Development Goals (MDGs), Universitas Terbuka Tangerang Banten (Vol. 10). https://doi.org/10.33830/ptjj. v19i2.325.2018

[24] Simkin, M. G., \& Kuechler, W. L. (2005). Multiple- choice tests and student understanding: what is the connection? Decision Sciences Journal of Innovative Education, 3(1), 7398. https://doi.org/10.1111/j.1540-4609.2005.00053.x

[25] Efe, H. A., Yucel, S., Baran, M., \& Sunkur, M. O. (2012). Influence of animationsupported project-based instruction method on environmental literacy and self-efficacy in environmental education. Asia-Pacific Forum on Science Learning and Teaching, 13(2), 113.

[26] Aedo, I., Díaz, P., Fernández, C., Martín, G. M., \& Berlanga, A. (2000). Assessing the utility of an interactive electronic book for learning the Pascal programming language. IEEE Transactions on Education, 43(4), 403-413. https://doi.org/10.1109/13.883350

[27] Nguyen, N., Williams, J., \& Nguyen, T. (2012). The use of ICT in teaching tertiary physics: Technology and pedagogy. Asia-Pacific Forum on Science Learning and Teaching, 13(2), 1-19.

[28] Hermansyah, H., Gunawan, G., \& Herayanti, L. (2015). Pengaruh penggunaan laboratorium virtual terhadap penguasaan konsep dan kemampuan berpikir kreatif siswa pada materi getaran dan gelombang. Jurnal Pendidikan Fisika dan Teknologi, 1(2), 97-102. https://doi. org/10.29303/jpft.v1i2.242 
[29] Sumtsova, O., Aikina, T., Bolsunovskaya, L., Phillips, C., Zubkova, O., \& Mitchell, P. (2018). Collaborative learning at engineering universities: Benefits and challenges. International Journal of Emerging Technologies in Learning (iJET), 13(1), 160-177. https://doi. org/10.3991/ijet.v13i01.7811

[30] Bi, X., \& Shi, X. (2019). On the Effects of Computer-Assisted Teaching on Learning Results Based on Blended Learning Method. International Journal of Emerging Technologies in Learning, 14(1). https://doi.org/10.3991/ijet.v14i01.9458

[31] Abuloum, A., Farah, A., Kaskaloglu, E., \& Yaakub, A. (2019). College Students' Usage of and Preferences for Print and Electronic Textbooks. International Journal of Emerging Technologies in Learning, 14(7). https://doi.org/10.3991/ijet.v14i07.9871

\section{Authors}

Ahmad Harjono is a lecturer and chair in the physics education study program in Mataram University.

Gunawan is a lecturer in the physics education study program in Mataram University. He is also believed to be the chair of the physics and technology education research center.

Rabiatul Adawiyah is a lecturer in physics education at the Islamic State University, Mataram - Indonesia.

Lovy Herayanti is a lecturer in the physics education study program, IKIP Mataram.

Article submitted 2019-06-01. Resubmitted 2019-10-23. Final acceptance 2019-11-01. Final version published as submitted by the authors. 